\title{
Development of the New Hybrid Evolutionary Algorithm for Low Vibration of Ship Structures
}

\author{
선박 구조물의 저진동 설계를 위한 새로운 조합 유전 알고리듬 개발
}

\author{
Young-Mo Kong, Su-Hyun Choi, Jin-Dae Song and Bo-Suk Yang \\ 공 영 모† · 최 수 현* 송 진 대**.양 보 석**
}

(Received April 17, 2006 ; Accepted May 19, 2006)

\begin{abstract}
Key Words : 유전 알고리듬(Genetic Algorithm), 반응표면법(Response Surface Methodology), 타부 탐색법 (Tabu Search Method)
\end{abstract}

\begin{abstract}
This paper proposes a RSM-based hybrid evolutionary algorithm (RHEA) which combines the merits of the popular programs such as genetic algorithm (GA), tabu search method and response surface methodology (RSM). This algorithm, for improving the convergent speed that is thought to be the demerit of genetic algorithm, uses response surface methodology and simplex method. The mutation of GA offers random variety to finding the optimum solution. In this study, however, systematic variety can be secured through the use of tabu list. Efficiency of this method has been proven by applying traditional test functions and comparing the results to GA. It was also proved that the newly suggested algorithm is very effective to find the global optimum solution to minimize the weight for avoiding the resonance of fresh water tank that is placed in the after body area of ship. According to the study, GA's convergent speed in initial stages is improved by using RSM method. An optimized solution is calculated without the evaluation of additional actual objective function. In a summary, it is concluded that RHEA is a very powerful global optimization algorithm from the view point of convergent speed and global search ability.
\end{abstract}

\section{요 약}

이 연구는 유전 알고리듬, 타부탐색법 그리고 반응표면법등 최근 많이 사용하고 있는 프로그램들의 장점들을 결합한 새로운 조합 유전 알고리듬을 제안한다. 이 알고리듬은 반응표면법 및 심플렉스법을 사용하여 유전알고리 듬의 약점으로 여겨지는 수렴속도를 항상 시키도록 하였다. 또한 유전 알고리듬에서 램덤 한 다양성을 제공하지 만, 이 연구에서는 타부리스트를 이용하여 체계적인 다양성을 추구하도록 하였다. 그리고 전통적인 시험함수에 본 알고리듬을 적용함으로써 이 방법의 효율성을 입중하였고 그 결과를 유전 알고리듬의 결과와 비교하였다. 또한 새 롭게 제안된 알고리듬을 선미부에 위치한 청수탱크의 중량최적화에 적용한 결과 전역 최적해를 효율적으로 찾는 것을 입증하였다. 또한 반응표면법을 사용한 새로운 유전알고리듬의 경우 실제 추가적인 목적함수를 평가하기 위 한 계산이 필요 없으므로 수렴속도가 일반 유전 알고리듬보다 향상되었음을 알 수 있었다. 마지막으로 제안된 조 합 유전 알고리듬은 전역탐색능력과 수럼속도 측면에서 매우 강력한 전역 최적화 알고리듬임을 알 수 있었다.

+ 책임저자; 정회원, 대우조선해양(주 진동소음연구팀

E-mail : ymkong@dsme.co.kr

Tel : (055) 680-5546, Fax : (055) 680-2142

* 정회원, 대우조선해양주) 진동소음연구팀

** 정회원, 부경대학교 기계공학부 


\section{Introduction}

Many dynamic analyses are focused on finding the maximum response and avoiding the resonance in a given structure under all excitation forces. ${ }^{(1.2)}$

Usually, these features provide the basis of a design limit and are thus employed to determine the dynamic characteristics of a structure and its weight. For this reason, weight minimization for reducing the response and avoiding resonance has always been a major concern to vibration analysts. Many classic optimization methods and commercial softwares have been developed and most of them are very effective, especially to solve the local optimum problems. However they are not so good tools to find a global optimum solution for the system. To overcome this disadvantage, many search algorithms have been developed seeking for a global optimum solution. One of the most popular methods is the genetic algorithm (GA). ${ }^{(3,4)}$ The GA is an optimization algorithm loosely inspired by evolutionary and is a powerful and general global optimization method. It does not require the strict continuity of classical search techniques, but it allows non-linearity and discontinuity to appear in the solution space. Due to the evolutionary characteristics, the GA can handle all kinds of objective functions and constraints defined on discrete, continuous, or mixed search spaces. However, the global access of the GA requires a computationally random search. So, the convergent speed to the exact solution is slow. Furthermore, the coding of the chromosome for a large dimensional problem will be very long, in order to get a more accurate solution. This results in a large search space and huge memory requirements for the computation. To overcome these demerits, many researchers have studied to develop many hybrid genetic algorithms which combine genetic algorithm with other ones. ${ }^{(5,6)}$ These can save computation time and find the global solution as far as it goes. However, new algorithms are required for better accuracy and faster convergent speed to get an optimum solution in the complicated and big structures like ships.

To seek for the optimum solution of multi-peak function with high accuracy and high speed, a new hybrid evolutionary algorithm is suggested in this study. This combines the merits of the popular programs such as GA, tabu search method, response surface methodology (RSM) and simplex method. The algorithm, for improving the convergent speed that is thought to be the demerit of GA, uses RSM and simplex method. The mutation of GA offers random variety to finding the optimum solution. However, systematic variety can be secured through the use of tabu list of tabu search method. Especially, in the initial stages, GA's convergent speed can be improved by using RSM which is using the information on the objective function acquired through GA process and then making response surface (approximate function) and optimizing this. The optimum solution is calculated without the evaluation of an additional actual objective function, and the GA's convergent speed is improved. Efficiency of this method has been proven by applying traditional test functions and comparing the results to GA. It was also proved that the newly suggested algorithm is very effective to find the global optimum solution to minimize the weight change for avoiding the resonance of fresh water tank that is placed in the after body area of ship.

\section{Concept of RSM-based Hybrid Evolutionary Algorithm (RHEA)}


The main idea is to reduce the evaluation number of the objective function by using RSM which is one among the designed experiments to reduce the repetitive number, since it is one of the demerits of optimum design. The RHEA consists of four main categories: GA for governing the general algorithm; tabu-list for systematic variety of solution; RSM for improving convergent speed for getting a candidate solution; modified simplex method for local search. Figure 1 represents the flowchart of the RHEA. The left side of the flow chart shows global search region that is similar to the flowchart of standard genetic algorithm, excluding the function assurance criterion (FAC), Sh (part A), tabu-list (part B), and RSM (part C). These parts offer candidate solutions, which are considered as initial search points in the local search region. The right side represents the local search region. This part finds out the optimum solution by the modified simplex method, which use the final solution by results of global search as initial search point.

Part A in Fig. 1 shows the Sh region which provides the well distributed points to make a

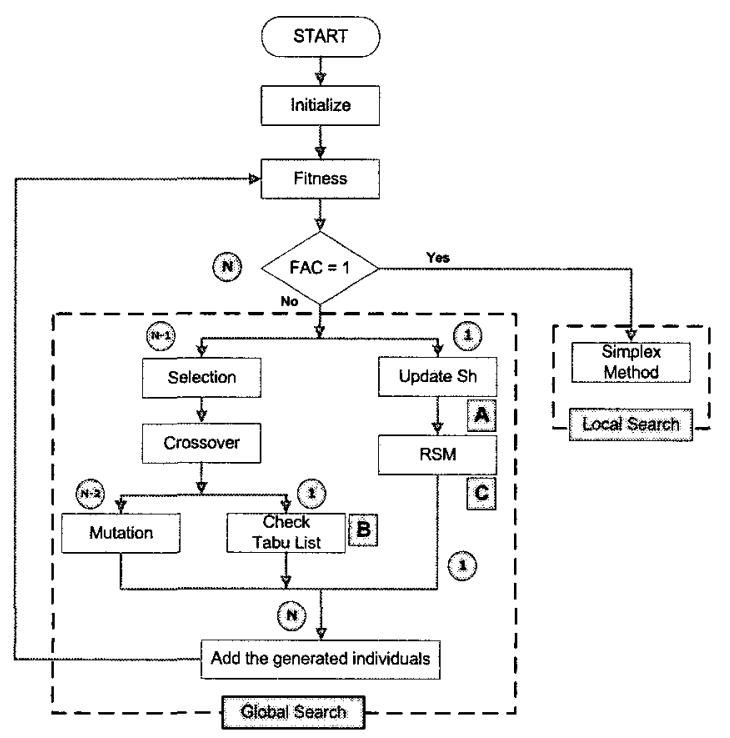

Fig. 1 Flowchart of RHEA response surface. Part $B$ in Fig. 1 shows that the tabu list is checked to have a diversity of solution. The one individual which is selected in GA's individuals after crossover is reviewed to secure the diversity of solution. If diversity of solution is secured, we select the individual and if not, we repeat the crossover process. That is, individual is selected when it is located far away from the dense area. Part C in Fig. 1 represents an $\mathrm{RSM}$ region. It is largely divided by 3 parts. Firstly, considering the boundary condition in the response surface for optimization, the upper and lower values of design variables can be considered in this calculation process. However, the merits of this method are diminished when addition constraints like natural frequency are considered, because it has to evaluate the objective function to get the results from external calculations. To overcome this problem, this study used $\mathrm{Sh}$ as training data and inferred the satisfaction of constraint condition using RBF (Radial Basis Function) network. ${ }^{(7)}$ In this way, calculation of actual problems could be avoided. Secondly, it makes a response surface from Sh by using the least square method (LSM). Finally, the optimum solution of the response surface is calculated by using tabu search method. To increase optimization speed, gradient based algorithm can be used. However, the solutions satisfying constraint condition cannot be guaranteed since the constraint condition is difficult to define precisely. Also we adopt tabu search method which has an excellent initial convergent speed, because the implementation of the response surface concept is to search for the approximate candidate solution.

\section{Procedures of RSM-based Hybrid Evolutionary Algorithm (RHEA)}


RSM-based hybrid evolutionary algorithm (RHEA) is introduced as follows:

Step 1: Generate the initial chromosome $v_{\mathrm{k}}$ $(\mathrm{k}=1,2, \cdots$, pop_size) randomly with $n$ elements.

Step 2: Generate the initial solutions, and estimate constraint and set up a parameter range.

Step 3: Evaluate the fitness of individuals.

Step 4: Evaluate the FAC, if it is satisfied, go to step 12 otherwise go to step 5 .

Step 5: Update Sh(a set of history) : Sh $=$ $\left\{\left(X_{\text {sh }}, F\right) \mid X_{\text {sh }} \in R^{N}, F \in R\right\}$. where $\mathrm{Xsh}=\left[x_{1}, x_{2}, \cdots, x_{i}, \cdots, x_{N}\right]$,

$N$ is number of design variables

Step 6: Selection.

Step 7 : Crossover and check tabu list.

Step 8: Construct response surface (RS) from Sh.

$$
f_{r s}=\alpha_{0}+\sum_{i=1}^{N} \alpha_{i i} x_{i}+\sum_{i=1}^{N} \alpha_{i i} x_{i}^{2}+\sum_{i=2}^{N} \sum_{j=1}^{i-1} \alpha_{i j} x_{i} x_{j}
$$

where $\alpha_{0}, \alpha_{i i}, \alpha_{i j}$ are coefficients calculated by LSM.

Step 9: Train RBF network by Sh to construct the constraint conditions approximately.

Step 10: Calculate the optimum design on the response surface by tabu search method and generate one individual based on $\mathrm{X}^{*}$.

Step 11: Mutate and go to step 3 .

Step 12: Search the optimum solutions by the local concentration search (modified simplex method) for best candidate.

\section{Numerical Examples of Using Test Function}

Three test functions were used to verify the efficiency of the proposed hybrid algorithm: the first one is the four-peak function ${ }^{(8)}$, which has one global optimum with three local optima ; and the second one is Rosenberk's

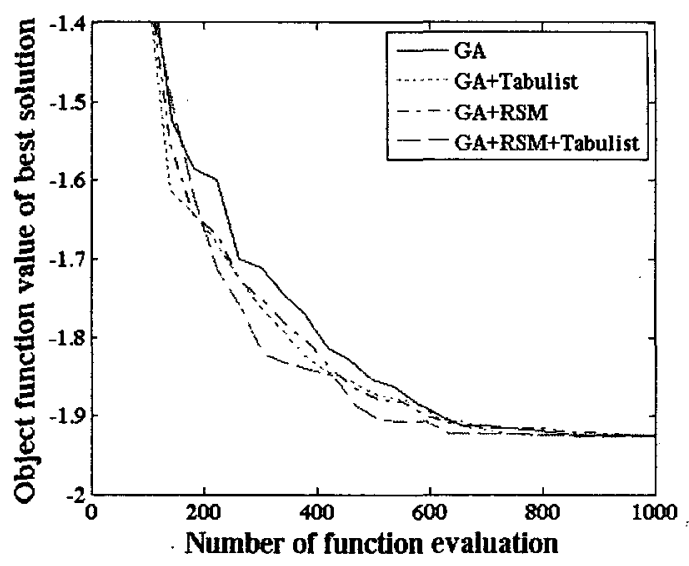

(a) Four-peak function

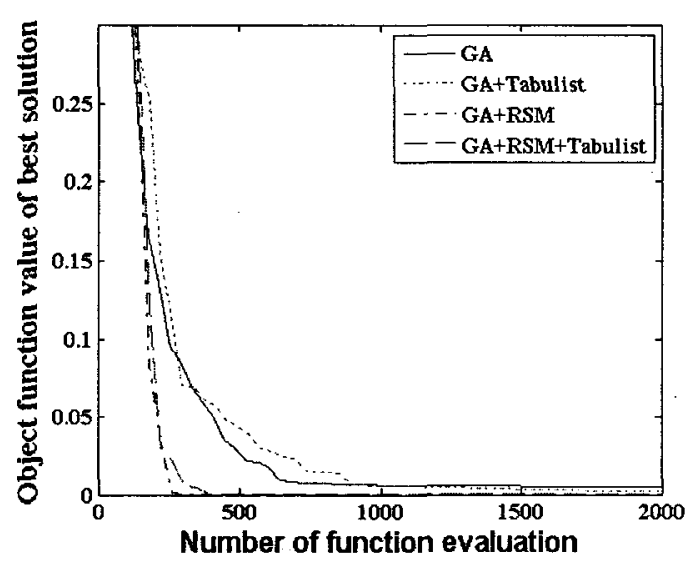

(b) Rosenbrook function

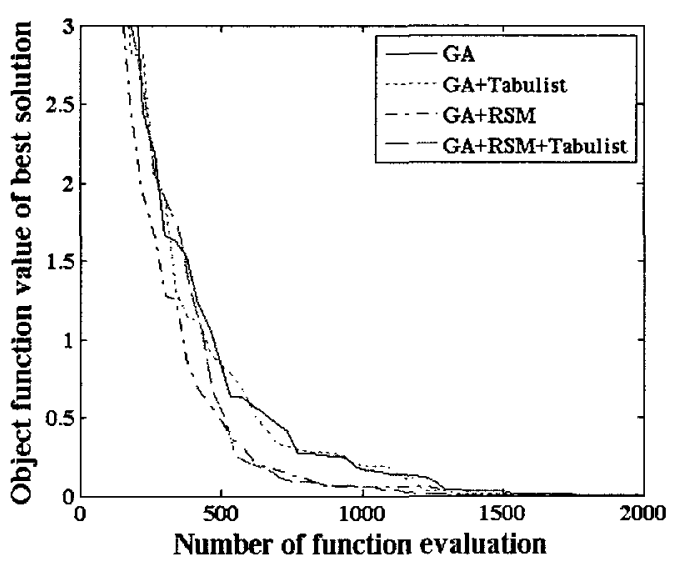

(C) Rastrigin function

Fig. 2 Convergent trend of objective function 
function $^{(9)}$ which is known as banana function and has just one global optimum; and the last one is the Rastrigin function ${ }^{(10)}$ which has one global minimum with 220 local minima.

Figure 2 represents the convergent trend of objective function for each test function. According to the results, GRSM (GA+RSM) and GRSMT (GA+RSM+Tabu list) algorithms which are based on RSM have faster convergent speed and more accurate solutions than GA, which validated the efficiency of RSM on the calculation. Also tabu list enables convergence to solutions quickly on the multi-peak function due to the systematic diversity of solution. Table 1 shows the comparison of optimization results for the above stated three test functions. The evaluation number means total evaluation number of the objective function used in optimization procedure and it is directly proportional to the total calculation time. According to the results, for all test functions, RHEA can give better solutions than GA on accuracy and convergent speed. For the Rastrigin function, which is very useful to evaluate the global search ability because there are many

Table 1 Comparison of optimization results

\begin{tabular}{|c|c|c|c|c|}
\hline \multicolumn{2}{|c|}{ Test function } & $\begin{array}{c}\text { Four-peak } \\
\text { function }\end{array}$ & $\begin{array}{l}\text { Banana } \\
\text { function }\end{array}$ & $\begin{array}{l}\text { Rastrigin } \\
\text { function }\end{array}$ \\
\hline \multicolumn{2}{|c|}{$\begin{array}{l}\text { Exact solutions } \\
\qquad f(x)\end{array}$} & $\begin{array}{c}1.95 \\
0 \\
0\end{array}$ & $\begin{array}{l}0 \\
1 \\
1\end{array}$ & $\begin{array}{l}0 \\
0 \\
0\end{array}$ \\
\hline \multirow{2}{*}{$\begin{array}{l}\text { Results } \\
f(x) \\
x_{1} \\
x_{2}\end{array}$} & $\mathrm{GA}$ & $\begin{array}{c}1.93 \\
2.4 \mathrm{E}-3 \\
2.79 \mathrm{E}-3\end{array}$ & $\begin{array}{l}1.64 \mathrm{E}-05 \\
9.96 \mathrm{E}-01 \\
9.96 \mathrm{E}-01\end{array}$ & $\begin{array}{l}1.59 \mathrm{E}-04 \\
1.41 \mathrm{E}-04 \\
8.15 \mathrm{E}-04\end{array}$ \\
\hline & $\begin{array}{l}\mathrm{RH} \\
\mathrm{EA}\end{array}$ & $\begin{array}{c}1.93 \\
2.74 \mathrm{E}-3 \\
2.74 \mathrm{E}-3\end{array}$ & $\begin{array}{l}0 \\
1 \\
1 \\
\end{array}$ & $\begin{array}{c}0 \\
-3.10 \mathrm{E}-09 \\
-7.80 \mathrm{E}-10\end{array}$ \\
\hline \multirow{2}{*}{$\begin{array}{c}\text { No. of } \\
\text { Evaluation }\end{array}$} & GA & 2353 & 1046 & 2109 \\
\hline & $\begin{array}{l}\text { RH } \\
\text { EA }\end{array}$ & 459 & 419 & 514 \\
\hline
\end{tabular}

local minima around the global minimum, RHEA found global minimum with higher accuracy and less elapsed time compared to GA. According to these results, the proposed new hybrid algorithm is a powerful global optimization algorithm from the view of convergent speed and global search ability.

\section{Application of Optimum Design to Fresh Water Tank of Ship}

In the engine room and the after body area of the ship, there are many tank structures in contact with fresh water, sea water or oil. Also these possibly subject to the excessive vibration during voyage because they are arranged around the main excitation sources of ship such as the main engine and propeller. If problems occur, it takes a lot of cost, time and effort to improve the situation because the reinforcement work for emptying the fluid out of the tanks, additional welding and special painting and so on is required. It is therefore very important to predict the precise vibration characteristics of the tank structures at the design stage. Optimum design needs to be applied. Especially when the structure is in contact with fluid much analysis time is taken. So, a new hybrid optimization algorithm is required for getting a short analysis time and accurate solution. In this study, optimum design of a fresh water tank in an actual ship is carried out to verify the validity of the proposed optimization algorithm (RHEA) and the results are compared to that of GA.

\subsection{Vibration Analysis of Fresh Water Tank} It is difficult to predict the vibration response of a local structure due to the complicated transfer mechanism of excitation force and the difficulty of assuming the damping ratio. Traditionally, the vibration analysis considering 
the design of avoiding resonance is conducted to prevent the local vibration.

In this study, the vibration analysis of the fresh water tank : is carried out using NASTRAN which is a . commercial finite element program and widely used for big structures like ships. Figure 3 shows the model and arrangement of the fresh water tank: Figure 4 shows the design variables and boundary condition of the fresh water tank. Considering the precision of analysis and time consuming modelling process, the range of modelling of fresh water tank is constrained to one side of the tank. The boundary conditions for the model are specified: the simple supports are used to the tank boundary area which is connected to the other bulkhead and deck.

In general, the design for avoiding local
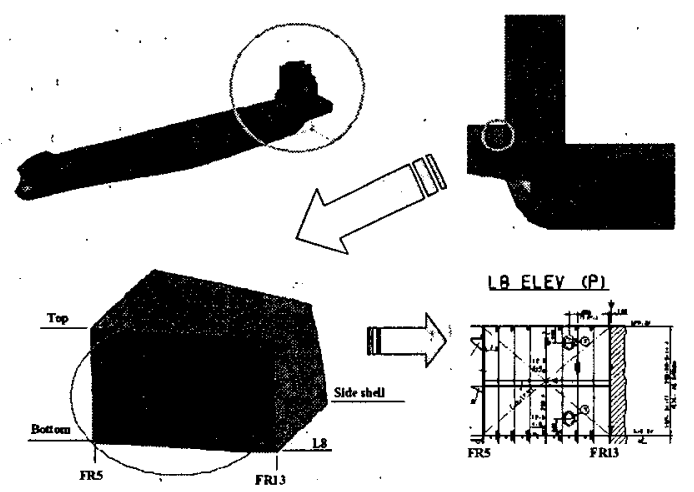

Fig. 3 Model and Arrangement of: fresh water tank
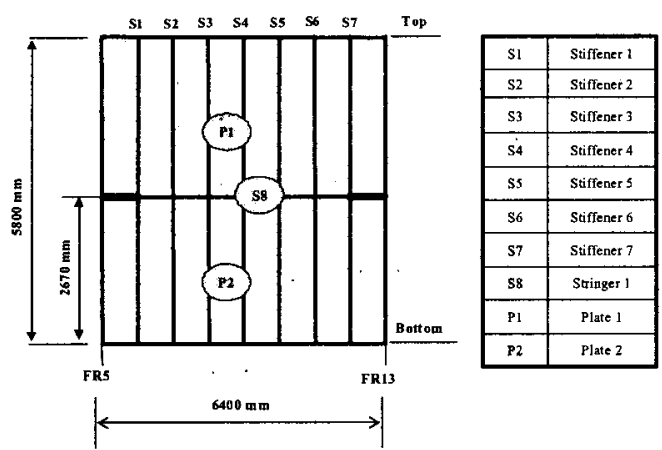

Fig. 4 Design variables and boundary conditions of fresh water tank structure resonance in ships requires that the natural frequency of the structure must be two times higher than the blade passing frequency of the propeller under the maximum rpm of the main engine. In this study, design target frequency is set as above $14.02 \mathrm{~Hz}$ which considers safety margins and twice blade passing frequency of the propeller $(12.13 \mathrm{~Hz})$.

Figure 5 shows the first three modes and natural frequencies of the fresh water tank by NASTRAN. These three modes frequently occurred on the fresh water tank during voyage. Especially, the 1 st mode $(8.60 \mathrm{~Hz})$ is a

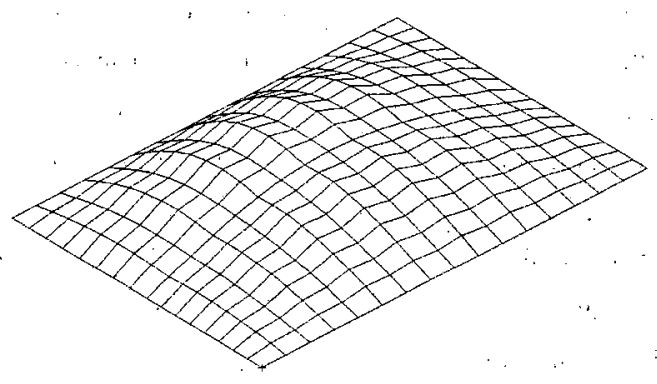

(a) 1 st mode $(8.60 \mathrm{~Hz})$

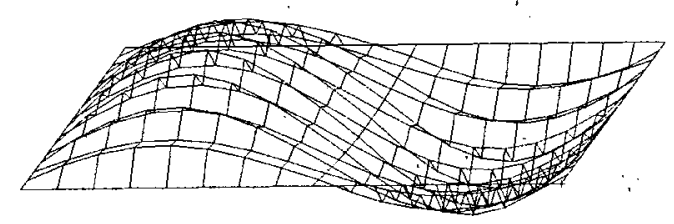

(b) 2nd mode $(18.82 \mathrm{~Hz})$

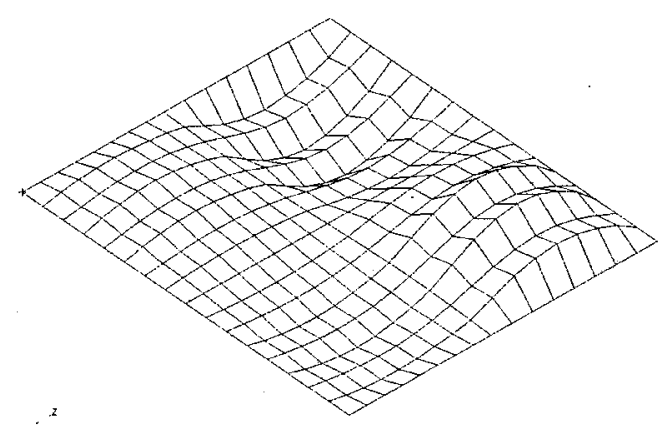

(c) 3rd mode $(19.17 \mathrm{~Hz})$

Fig. 5 Mode shapes of fresh water tank 
stiffener (stringer) mode which generates a strong vibration and much effect on the structure. In this model, the 1st natural frequency of the structure is also within the resonance region where twice blade passing frequency of propeller is $12.13 \mathrm{~Hz}$. Therefore, the natural frequency of structure is needed to be increased up to the target frequency under the condition that the tank is fully filled. The natural frequency of structure which is in contact with fluid can be changed according to the water line of the tank. So, in order to design a safe structure, the three modes of the fresh water tank are concerned in this study.

\subsection{Optimum Design of Fresh Water Tank}

Design variables: The main vibration modes on the fresh water tank are stiffener modes in transverse direction. One of the most important factors is the stiffness of stiffeners. In this study, the stiffener size and plate thickness of fresh water tank in Fig. 4 are defined as design variables in Eq. (2).

$$
\boldsymbol{x}=\{\mathrm{S} 1 \mathrm{~S} 2 \mathrm{~S} 3 \mathrm{~S} 4 \mathrm{~S} 5 \mathrm{~S} 6 \mathrm{~S} 7 \mathrm{~S} 8 \mathrm{P} 1 \mathrm{P} 2\}^{\mathrm{T}}
$$

where $\mathrm{S}$ and $\mathrm{P}$ mean stiffener size and plate thickness, respectively.

Constraints: The web length of stiffener $L w$ is restricted as two categories like Eqs. (3) and (4) according to the shipyard's practice.

$$
\begin{aligned}
& 150 \leq \boldsymbol{L} w \leq 450 \mathrm{~mm} \text { for stiffeners (S1-S7) } \\
& 500 \leq L w \leq 1000 \mathrm{~mm} \text { for stringer (S8) }
\end{aligned}
$$

The basic concept of local vibration design is also the minimization of the response at each point. However, it is difficult to evaluate how much the excitation force influences on local structure. So, in this study, natural frequency of the structure is restricted as Eq. (5) which considers a safety margin of twice blade passing frequency of the propeller.

$$
\omega_{n} \geq 14.02 \mathrm{~Hz}
$$

Objective function: The objective function combines linearly the weight of fresh water tank with natural frequency of structure like Eq. (6). The objective is to get an economic and sound structure to reduce the weight of stiffener and to increase the natural frequency.

$$
\text { Minimize } f(x)=\alpha\left(\frac{W_{1}}{W_{0}}\right)+\beta\left(\frac{\omega_{t}}{\omega_{0}}\right)
$$

where, $W_{1}$ and $W_{0}$ mean current and original weight of stiffeners and plates, respectively. $\omega_{t}$ and $\omega_{0}$ mean target and current natural frequency, respectively. $\alpha$ and $\beta$ are weighting factors ( $\alpha=0.5, \beta=0.5)$.

\subsection{Optimization Results and Discussion}

The optimum design was carried out to get an optimal size of stiffener and plate thickness on the fresh water tank to maintain the anti-vibration design of it. Table 2 shows the results of the design variables before and after optimization. It shows that the stringer $\mathrm{S} 8$ is increased by $72 \%$ and the others by $4.0 \sim 52$ $\%$. This result indicates that the most reasonable modification method is to increase the stringer which has an effect on the decreasing the span of the vertical stiffeners. In this case, however, the plate thickness does not have any effect on the natural frequency of the structure. Table 3 shows the variation of natural frequency and weight of structure before and after optimization. According to the results, the 1 st natural frequency increased by $163 \%$ from $8.6 \mathrm{~Hz}$ to $14.02 \mathrm{~Hz}$, and the safety margin with twice passing frequency of the propeller correspondingly changed from -29.1 $\%$ to $11.56 \%$. Therefore, the structure is free from resonance. Moreover, the weights of stiffeners which are applied to the design 
Table 2 Comparison of original and optimal design variable .

\begin{tabular}{c|c|c|c|c}
\hline \multirow{2}{*}{$\begin{array}{c}\text { Design } \\
\text { variable }\end{array}$} & \multirow{2}{*}{ Original } & \multicolumn{2}{|c|}{ Optimum } & \multirow{2}{*}{ Remark } \\
\cline { 3 - 5 } & & $\mathrm{GA}$ & RHEA & \\
\hline S1 & 200 & 214 & 207 & $4.00 \%$ \\
\hline S2 & 200 & 320 & 223 & $12.00 \%$ \\
\hline S3 & 200 & 253 & 285 & $43.00 \%$ \\
\hline S4 & 200 & 325 & 283 & $42.00 \%$ \\
\hline S5 & 200 & 328 & 303 & $52.00 \%$ \\
\hline S6 & 200 & 277 & 251 & $26.00 \%$ \\
\hline S7 & 200 & 281 & 230 & $15.00 \%$ \\
\hline S8 & 550 & 893 & 947 & $72.00 \%$ \\
\hline P1 & 11 & 10.7 & 10.3 & $-6.36 \%$ \\
\hline P2 & 11 & 10.6 & 10 & $-9.90 \%$ \\
\hline
\end{tabular}

Table 3 Comparison of results

\begin{tabular}{c|c|c|c}
\hline Item & Original & Optimum & Remarks \\
\hline $\begin{array}{c}\text { Natural } \\
\text { frequency }\end{array}$ & $8.60 \mathrm{~Hz}$ & $14.02 \mathrm{~Hz}$ & $163 \%$ \\
\hline Weight & $4883 \mathrm{~kg}$ & $4652 \mathrm{~kg}$ & $-4.73 \%$ \\
\hline
\end{tabular}

Table 4 Comparison of optimization results

\begin{tabular}{c|c|c|c}
\hline \hline Item & Weight & $\begin{array}{c}\text { Objective } \\
\text { function }\end{array}$ & $\begin{array}{c}\text { No. of } \\
\text { evaluation }\end{array}$ \\
\hline GA & $5001 \mathrm{~kg}$ & 0.5547 & 1846 \\
\hline RHEA & $4652 \mathrm{~kg}$ & 0.5167 & 1638 \\
\hline
\end{tabular}

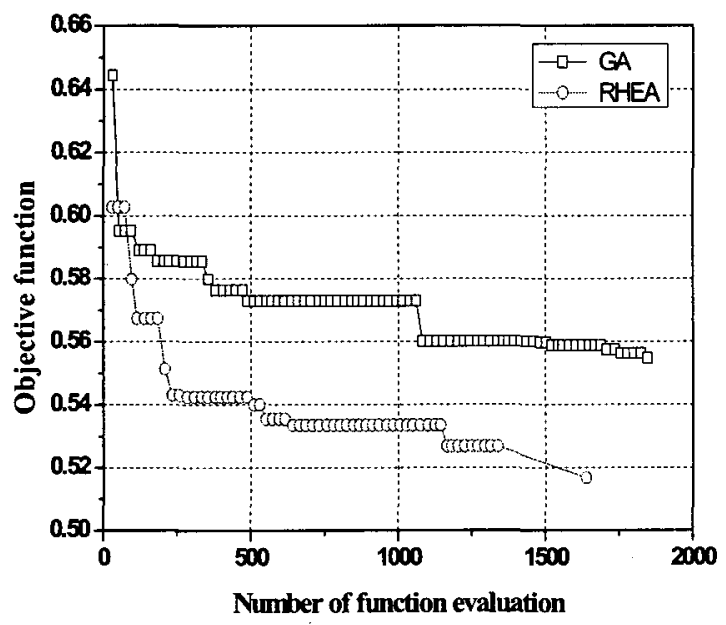

Fig. 5 Convergence of objective function variables also decreased in spite of higher natural frequency. In summary, the local vibration problems which require avoidance of structure resonance through the movement of natural frequency without additional weight has been successfully solved by the proposed optimization method. Table 4 and Fig. 5 show the comparison of optimization results between GA and RHEA. The evaluation number means a total evaluation number of the objective function used in the optimization procedure and it is directly proportional to the total calculation time. According to the results, RHEA can give better solutions than GA on accuracy and convergent speed. These results lead us to draw the conclusion that the proposed new hybrid algorithm is a more powerful global optimization algorithm from the view of convergent speed and global search ability.

\section{Conclusions}

This paper introduces RSM-based hybrid evolutionary algorithm, as a new kind of a hybrid optimization algorithm that combines the merits of the popular programs such as genetic algorithm, tabu search method and response surface methodology. This algorithm, for improving the convergent speed that is thought to be the demerit of genetic algorithm, uses response surface methodology and simplex method. The mutation of GA offers random variety to finding the optimum solution. In this study, however, mutation offers systematic variety to finding the optimum solution through the use of tabu list. Especially, in the initial stages, GA's convergent speed can be improved by using RSM which is using the information on the objective function acquired through GA process and then making response surface (approximate function) and optimizing this. The optimum solution is calculated without 
the evaluation of an additional actual objective function, and the GA's convergent speed is improved. Efficiency of this method has been proven by applying traditional test functions and comparing the results to GA. It was also proved that the newly suggested algorithm is very effective to find the global optimum solution to minimize the weight for avoiding the resonance of fresh water tank that is placed in the after body area of ship.

Finally it is concluded that the proposed new hybrid algorithm (RHEA) is a very powerful global optimization algorithm from the view point of convergent speed and global search ability.

\section{References}

(1) Kitamura, M, Nobukawa, H. and Yang, F, 2000, "Application of a Genetic Algorithm to the Optimal Structural Design of a Ship's Engine Room Taking Dynamic Constraints into Consideration," Marine Science and Technology, Vol. 5, pp. 131 146.

(2) Yang, B. S., Kong, Y. M., Choi, S. H., Chae, S. I., Song, S. D. and Kim, Y. H., 2005, "Development of NASTRAN-based Optimization Framework for Vibration Optimum Design of Ship Structure," Transactions of the Korean Society for Noise and Vibration Engineering, Vol. 15, No. 11, pp. $1223 \sim 1231$.

(3) Goldberg, D. E., 1989, "Genetic Algorithms in Search, Optimization \& Machine Learning," Addison-Wesley Publishing Company, pp. 1 146.

(4) Davis, L., 1991, "Handbook of Genetic Algorithms," Van Nostrand Reinhold, New York, pp. $3 \sim 23$.

(5) Kim, Y. C. and Yang, B. S., 2002, "An Enhanced Genetic Algorithm for Global and Local Optimization Search," Transactions of the KSME (A) Vol. 26, No. 5, pp. $1008 \sim 1015$.

(6) Sato, T. and Hagiwara, M., 1998, "Bee System: Finding Solution by a Concentrated Search," T. IEE Japan, Vol. 118-C, No. 5, pp. 721 $\sim 726$.

(7) Howard, D., Mark, B. and Martin, H., 2005, "Neural Network Toolbox for Use with MATLAB," The MathWorks.

(8) Kim, Y. C., 2003, "Development of Enhanced Genetic Algorithm and Its Applications to Optimum Design of Rotating Machinery," Ph. D. Dissertation, Pukyong National University, South Korea.

(9) Homaifar, A., Qi, C. and Lai, S., 1994, "Constrained Optimization via Genetic Algorithm Simulation. Electronics Letter," Vol. 62, No. 4, pp. $242 \sim 254$.

(10) Kim, Y. H., Yang, B. S., Kim, Y. C. and Lee, S. J., 2003, "Bearing Parameters Identification Using Hybrid Optimization Algorithm," in Proceedings of 32nd International Congress and Exposition on Noise Control Engineering, Jeju, Korea, pp. $4212 \sim 4219$. 